\title{
LOCUS OF CONTROL AND ONLINE LEARNING
}

\author{
SURETHA ESTERHUYSEN \\ KAREL J STANZ \\ Programme in Leadership in Performance and Change \\ Department of Human Resource Management \\ Rand Afrikaans University \\ kst@eb.rau.ac.za
}

\begin{abstract}
The integration of online learning in university courses is considered to be both inevitable and necessary. Thus there is an increasing need to raise awareness among educators and course designers about the critical issues impacting on online learning. The aim of this study, therefore, was to assess the differences between two groups of first-year Business Sciences learners (online and conventional learners) in terms of biographic and demographic characteristics and locus of control. The study population consisted of 586 first-year learners of whom 185 completed the Locus of Control Inventory (LCI). The results show that the two groups of learners do not differ statistically significantly from each other with respect to locus of control. The findings and their implications are also discussed.
\end{abstract}

\section{OPSOMMING}

Die integrasie van aanlyn-leer in universiteitskursusse word beskou as sowel onafwendbaar as noodsaaklik. Daar is dus 'n toenemende behoefte om bewustheid onder opvoedkundiges en kursusontwerpers te kweek oor die kritiese aspekte wat 'n impak op aanlyn-leer het (Morgan, 1996). Daarom was die doel van hierdie ondersoek om die verskille tussen twee groepe eerstejaarleerders in Bestuurs- en Ekonomiese Wetenskap (aanlyn en konvensionele leerders) te bepaal ten opsigte van biografiese en demografiese eienskappe en lokus van beheer. Die populasie het bestaan uit 586 eerstejaarleerders waarvan 185 die Lokus van Beheer Vraelys voltooi het. Die resultate toon dat die twee groepe leerders nie statisties beduidend van mekaar verskil het met betrekking tot lokus van beheer nie. Die bevindinge en implikasies word ook bespreek.

It cannot be denied that the Internet should play an integral role in education. Its application was introduced in 1969 when a number of United States universities established the first electronic connections that initiated the net. Today, more and more learning takes place in an online environment (McFadzean, 2001a). Online learning is part of the biggest change in the way our species learn since the invention of the chalkboard or perhaps even the alphabet (Horton, 2000). Barriers of space and time have been removed by the development of computers and electronic communication media, and knowledge can be obtained and delivered anytime anywhere. John Chambers, CEO at Cisco, has prophesied that the net's "next big killer application" will be education and that the scale of network traffic generated by online education will make today's exchange of e-mail messages look like a rounding error (Worthington Smith, Rockey, Siebert \& Hartley, 2001).

Many studies highlight the need for research to be conducted in the various areas of online education (Russell, 2002; Charp, 1999). There is also an increasing need to raise awareness among educators and course designers about the critical issues impacting on online learning (Morgan, 1996). As demands for lifelong learning increase, the demands on higher education to become more accessible and more learner driven will increase (Higher Education's Role in the Digital Age, 1999).

Universities experience a huge demand for courses taught online and do not wish to be swept aside by competitors from the commercial sector. Hence they are pressuring their faculties to provide opportunities for online learning (Smith, Ferguson \& Caris, 2001). Now is the time to harness the power of online learning for the benefit of tertiary institutions in South Africa (Smith et al., 2001). According to Follows (1999), an online learning environment is the ideal learning environment. But is it better for everyone? Who is likely to participate in online learning? Schlosser and Anderson (1994) reviewed distance education and found no study investigating the characteristics of online learners.

Requests for copies should be addressed to: KJ Stanz, Department of Human Resource Management, RAU University, PO Box 524, Auckland Park, 2006,
This study is therefore an attempt to investigate whether there are differences between the locus of control of online university learners and conventional university learners.

All over the world there is a social and political momentum towards expanding higher education to reach greater numbers of learners of all ages and backgrounds at times and locations that suit them. This transformation comes at a time when technical innovations, in particular the World Wide Web, are having a major impact on the way we work, conduct business, communicate with each other, and learn (Littlejohn \& Sclater, 1999).

There is widespread support for lifelong learning and its importance can hardly be over-stated as we seek to maintain competitiveness in a rapidly changing world. Life-long learning can become a reality through online learning (Davies, 1998) "Using the Internet to deliver flexible, fast, appropriate learning that is tailored to user requirements makes the transition to the new economy rapid, seamless and effective" (Goldschmidt, 2001). It is clear that the use of online learning is transforming the learning industry and business educational establishments (McFadzean, 2001b).

Meanwhile universities are subject to continual reductions in funding and are being forced to attract learners in an increasingly competitive environment (Littlejohn \& Sclater, 1999) and a society where life-long learning, in other words continuous learning (Knasel, Meed \& Rossetti, 2000), is a priority. For people in developed as well as developing nations all over the world, rapid change is a fact of life. The entire globe has plunged into the Information Era, resulting in accelerated change with enormous consequences for learning (Davis \& Davis, 2000).

Providing online learning programmes for the large number of learners who are unable to attend lectures on a daily basis is becoming imperative, as the demand for such courses and the competition for learners are huge (Smith et al., 2001).

According to Goldsmith (2001) and Garten (2000) learners tend to differ in their attitudes towards online learning. Some learners thrive on face-to-face interaction and will therefore miss this type of communication when they 
engage in online learning. Some learners experience anxiety about technology (Santo, 1999). Others are intrigued by an electronically mediated exchange and will appreciate the opportunity it offers for thoughtful communication and voicing of opinions.

Learning in an online environment often affords learners a high degree of control over their learning experience, but an important finding in the educational literature is that many learners who are given control over their learning choose to terminate the experience before mastering the learning (Steinberg, 1989; Tennyson, 1980). The possibility that some adult learners may make choices that will limit their learning in online learning environments is an important practical concern for facilitators of learning. If many learners make poor choices in online learning environments, then the current trend of converting learning from classroom to computers may reduce learning outcomes (Brown, 2001).

\section{Online learning}

Many words are used in the literature to refer to learning that takes place over the Internet. (Tennyson, 1980; Piskurich, 1993; Williams \& Zahed, 1996; Hall, 1997; Davies, 1998; Driscoll, 1998; Follows, 1999; Santo, 1999; Berry, 2000; Galagan, 2000; Garten, 2000; Horton, 2000; Lee \& Owens, 2000; Kruse \& Keil, 2000; Wang and Newlin, 2000; Brown, 2001; Smith, Ferguson \& Caris, 2001; Goldschmidt, 2001; Goldsmith, 2001; Van Tonder, 2001; Burrows, 2002; McFadzean, 2001a; McFadzean, 2001b.)

Some writers call it Web-Based Training (WBT) (Hall, 1997; Driscoll, 1998; Horton, 2000; Lee \& Owens, 2000) others call it computer-based training (CBT) (Williams \& Zahed, 1996; Brown, 2001). Tennyson (1980) calls it "computer-based instruction", Wang and Newlin (2000) refer to "web-based classes", Berry (2000), Galagan (2000), Goldschmidt (2001), Van Tonder (2001) and Burrows (2002) call it "e-learning", and Davies (1998), Follows (1999), Santo (1999), Garten (2000) and McFadzean (2001a, 2001b) use the term "virtual learning". "Online learning" (Goldsmith, 2001; Smith et al., 2001), "technology-based training" (Kruse \& Keil, 2000) and even "self-directed learning" (SDL) (Piskurich, 1993) are other terms in use. Although there are some technical distinctions among these types of learning, they all involve the use of computers as the dominant medium for delivering instruction to learners. This study opts for "online learning".

Tertiary education used to be something you pursued before you took your first permanent job. But in the new economy, learning is a lifelong enterprise and learners engage more and more in online learning. Among the amplifying ranks of home schooling parents, the Internet is the place to turn for research, course work and support. In higher education, online learning enables all sorts of nontraditional learners those with families, full-time jobs or other responsibilities to obtain college diplomas and university degrees (Van Tonder, 2001).

Meanwhile, increasing numbers of corporations are looking to online training methods to meet basic employee-training needs (Van Tonder, 2001). Some corporations are even providing laptops to their employees in support of the theory that education is a lifelong as opposed to a single-moment experience. Online learning is taking flight, because the online learning industry is getting technology and content to work together in a timely fashion.

A growing number of companies find that the Web is the best delivery tool for courses aimed at broadening staff skills. They are moving from a single mode of training to a mode of training that offers multiple modalities such as classrooms and distance-learning facilities combined (live e-learning) to provide their employees with continued learning experiences (Van Tonder, 2001).

Follows (1999) reviewed online learning and identified the following benefits: It provides learners with context for the learning process; allows the learner to control the learning process; develops an ability to solve high-level problems, especially problems that are ill-structured; makes learning a personal experience for the learner; models the complexities and uncertainties of working in the real world; and accommodates a wide range of learning styles.

Online learning is changing the landscape of learning, much like a tornado sweeping through a wheat field (Galagan, 2000). It is no longer necessary to convince anyone that it is necessary to make the transition from conventional to online learning. John Cone, vice president of Dell Learning at Dell Computer Corporation said, "Our conversations today are not about 'Shall we do this?' They're about 'How shall we do it?' We know that we want to move online to make learning more scalable, flexible, and focused on learners' needs. Now, the question is 'How do we reap the benefits?" (Galagan, 2000).

Learners no longer have a choice as to whether to get involved in online learning or not; they have to engage in it if they want to survive in the ever-changing workplace in the Information Age. The Information Age is increasing the demand for selfdirected adults (Hengstler, 2001) who can learn effectively in an online learning environment.

During adolescence learners make great strides towards adulthood through self-direction, self-determination or self-regulation, concepts that are central to the achievement of adult status (Hengstler, 2001). This development towards adulthood and self-directed learning is greatly influenced by amongst other factors, learners' perceived control or locus of control.

\section{Locus of control}

"Locus of control" is a multi-dimensional construct that is aimed at capturing the causality of behaviour (Erwee, 1986). The construct relates to the expected outcome of actions (Rotter, 1966; Lefcourt, 1976) and not the actions themselves. According to Bothma and Schepers (1997) locus of control refers specifically to beliefs about the source of control over reinforcement.

The construct of internal versus external locus of control of reinforcement is a part of Rotter's (1966) social learning theory (Bothma \& Schepers, 1997). Rotter (1966) argued that people could be placed along a continuum in respect of the extent to which they typically see what happens to them as dependent on their own control or the control of external forces.

At the one end of the continuum we find internals, who generally maintain that the outcomes in their lives depend largely on their own actions and choices. They believe that outcomes are a consequence of own striving, ability and initiative (Burger, 1992). They feel responsible for the consequences of their actions and their locus of control is internal to themselves (De Charms, 1968). At the other end we find externals who believe that there is little one can do to influence outcomes; they believe that these outcomes are independent of their own behaviour and attribute outcomes to chance, social structures, fate or powerful other people (O'Brien, 1986; Burger, 1992). In short, internals are more inclined than externals to perceive their behaviour as instrumental in obtaining desired outcomes and avoiding undesirable outcomes (Leone \& Burns, 2000) 
Locus of control is "a generalised expectancy about the extent to which reinforcements are under internal or external control" (O'Brien, 1986, p. 52). O'Brien explains that there are two extremes. On the one extreme one finds externally controlled people who believe that reinforcements are determined largely by other people, social structures, luck or fate. They act as though forces beyond their control are important factors in determining the occurrence of reinforcing events (Stone \& Jackson, 1975). The other extreme is internally controlled people who believe that reinforcements are determined largely by personal effort, ability and initiative. These people believe that they have control over reinforcing events in their lives (Stone \& Jackson, 1975).

Internals and externals differ in relation to their cognitive activity and environmental mastery. Internals seem to exert more control over their lives because they are more perceptive of their situations. They will more readily acquire and utilise information that is relevant to their goal situation, even when it is seemingly irrelevant (Dollinger, 2000).

Dollinger (2000) found that internals surpass externals on incidentally acquired and seemingly trivial knowledge, which nevertheless has relevance for learners' academic success. He indicated that facilitators should suggest to learners who tend to agree with external control statements the value of "behaving like an internal" if they wish to succeed in college. Dollinger's (2000) research provided evidence that being an active agent in one's education and paying attention even to the seemingly trivial things correlate with academic success; and Lau and Shaffer (1999) concluded that individuals with high internal control were more successful in their careers than those who scored high in external control.

Biggs (1985) and Rose, Hall, Bolen and Webster (1996) referred to studies that suggested an association between critical thinking skills and locus of control. These studies concluded that learners who are disinterested in critical thinking skills or lack intrinsic motivation or curiosity are likely to have an external locus of control. On the other hand, learners who adopt a "deep approach to learning" (i.e. those who have intrinsic motivation and curiosity, and who often reflect upon what they learn) tend to have an internal locus of control (Rose et al., 1996). Ishiyama, McClure, Hart and Amico (1999) argued that this suggests that learners who have an internal locus of control would prefer learning environments that maximise their degree of control over their learning, and online learning will provide such an environment.

Various South African studies (De Kock \& Roodt, 1995; Rieger \& Blignaut, 1996; Le Roux et al., 1997; Bothma \& Schepers, 1997; Van Staden, Schepers \& Rieger, 2000; Rothmann \& Agathagelou, 2000) have also explored the concept of locus of control in relation to other concepts. De Kock and Roodt (1995) attempted to establish the effects of intelligence on the relationship between locus of control and task complexity and concluded that no statistically significant relationship exists; Rieger and Blignaut (1996) researched individuality, collectivity and locus of control as micro variables of diversity and concluded that individuality correlates positively with both internal locus of control and autonomy while external locus of control and collectivity do not correlate.

Le Roux et al. (1997) researched achievement motivation, locus of control and individuality as predictors of participative management and found that those respondents who demonstrated a stronger inclination towards participative management also demonstrated a greater degree of locus of control as well as a greater need for autonomy. Bothma and Schepers (1997) looked at the role that locus of control and achievement motivation play in work performance and concluded that the Locus of Control Inventory (LCI) is a better predictor of work performance than achievement motivation, while Van Staden et al. (2000) investigated the relationship between locus of control and transformational leadership. The results indicated statistically significant relationships between: internal locus of control and transformational leadership; external locus of control and transactional leadership; and autonomy and transformational leadership.

Rothmann and Agathagelou (2000) searched for a relationship between locus of control and job satisfaction and found that a correlation of large effect exists between locus of control and job satisfaction. They found a moderate negative correlation between an external locus of control and job satisfaction.

Various instruments have been developed to measure the construct of locus of control (Le Roux, Schmidt \& Schepers, 1997). Rotter (1966) developed the locus of control questionnaire, namely the Internal-External (I-E) Scale. Although several other instruments have been developed, Rotter's I-E Scale appears to be used the most frequently (Schepers, 1994). However, a significant drawback of Rotter's I-E Scale is the fact that the forced choice item format leads to ipsative measurements, while a user of the questionnaire generally requires a normative measurement (Schepers, 1994). Le Roux et al. (1997) state that ipsative measurements are not necessarily considered inadequate, provided that its limitations are recognised.

According to Clemans (1956) ipsative scores are relative scores, which imply that it is quite possible that a person obtaining a high ipsative score on a particular trait actually possesses less of the characteristic in question than a respondent obtaining a much lower ipsative score. It is therefore imperative that ipsative scores are only interpreted in the relative sense (Clemans, 1956).

Locus of control and online learning

Relatively little is known about the characteristics of learners who choose to enroll for courses in an online learning environment, since web-based technology and courseware are fairly new (Wang \& Newlin, 2000). Schlosser and Anderson (1994) published a report titled Distance education: Review of the literature in which they did not cite a single study on the characteristics of online learners.

Against the backdrop of this lack of information on the characteristics of online learners the research presented in this report will provide some insight. Dille and Mezack (1991a, 1991b) reported that locus of control can discriminate between learners taking either an online or a conventional course. They found that learners with an internal locus of control are more likely to persist in distance education than those with an external locus of control.

Wang and Newlin (2000) found a significant difference between online learners (those who enrolled for web-based classes in Psychology) and conventional learners (those who enrolled for face-to-face classes). Online learners exhibited a greater external locus of control than their counterparts in conventional courses.

However, according to Ishiyama et al. (1999) the fact that a learner's locus of control may affect the evaluation of facilitation strategies must be taken into consideration. Ishiyama et al. (1999) suggested that learners who have an internal locus of control should prefer learning environments that maximise their degree of control over their learning, and that an online learning environment may be just such an environment.

The Internet has already changed the way we do business and the way we learn; and will continue to do so in the future 
(http://www.campuswise.co.za/campuswise/index3.htm). However, online learning itself can only form an effective part of integrated learning programmes when it is managed correctly.

Skillwise director Dr. Robin Stead says that people often voice fear of the use of technology in learning, as technology increases the risk of rendering the facilitator redundant (Burrows, 2002). Online learning fundamentally transfers the locus of control from the facilitator to the learner (Galagan, 2000; McFadzean, 2001a). This has tremendous practical implications, namely that facilitators of learning have to give up some control of the learning process and that learners then have to take control of their own learning, although certain learners will be disinclined to do so.

Learners no longer have a choice as to whether to get involved in online learning or not; they have to engage in it if they want to survive in the ever-changing workplace in the Information Age. The Information Age is increasing the demand for selfdirected adults (Hengstler, 2001) who can learn effectively in an online environment.

During adolescence learners make great strides toward adulthood through self-direction, self-determination or self-regulation (Hengstler, 2001). This development towards adulthood and selfdirected learning is greatly influenced by the learner's perceived control or locus of control.

The learning environment and interaction with it have been shown to contribute significantly to learner development during adolescence. Adolescents experience great pressure to develop and attain self-direction in an online environment. Adolescent learners in such an environment experience a much higher level of autonomy than afforded in a "traditional" classroom, but they will only be effective if they can manage this environment (Hengstler, 2001).

Research on the influence of locus of control on learner involvement in online learning will benefit the individual and the organisation. Knowledge of this aspect can assist individual learners to realise that it might be necessary to develop strategies to adjust their normal locus of control in order to achieve academic success (Dollinger, 2000) and also career success (Lau \& Shaffer, 1999). At the organisational level, knowledge of the influence of locus of control on online learning can help education, training and development practitioners to design effective online learning programmes.

An understanding of the factors that prevent learners from getting involved in online learning will be valuable for facilitators of online learning. This study might shed some light on locus of control as a factor in learners' involvement in online learning. Knowledge about the locus of control in online learning can assist facilitators to find strategies for designing and coordinating online learning programmes. Facilitators of online learning will have to look at methods to accommodate and motivate both learners with an internal locus of control and learners with an external locus of control.

The research question is whether a learner's locus of control has an influence on his/her tendency to voluntarily get involved in online learning.

\section{Hypotheses}

In view of the above, the principal aim of this study was to determine whether there are significant differences between online university learners and conventional learners with respect to locus of control.

The following hypotheses were formulated:

$\mathrm{H}_{0}$ : The vectors of means of the two groups with respect to locus of control will not differ statistically significantly from one another.
$\mathrm{H}_{\mathrm{A}}$ : The vectors of means of the two groups with respect to locus of control will differ statistically significantly from one another.

$\mathrm{H}_{\mathrm{A1}-3}$ : The vector of means of the two groups with respect to the three scales of locus of control will differ statistically significantly from one another.

$\mathrm{H}_{\mathrm{A} 1-3:} \mathrm{A} 1=$ Autonomy, $\mathrm{A} 2=$ External, $\mathrm{A} 3=$ Internal.

\section{METHOD}

Research design

This study is a quantitative study since the variables can be operationalised in terms of specific measuring instruments (Mouton \& Marais, 1991). There is no control of variables and the independent variable is not manipulated. The study is also exploratory and descriptive as well as retrospective (because it was done on retrospective data). Elements of the design are predetermined. In addition it is ex post facto (after the fact), also known as "causalcomparative" (Cooper \& Schindler, 2001), and non-experimental (www.ais.msstate.edu/AEE/8803/class 4/tsld017.htm, www.cedu.niu.edu/ smith//PP_presentation/15_causalcomp.ppt). The method attempts to show causes and consequences after they have occurred, but no causal inferences can be drawn and there is no manipulation of independent variables. A strength of this research design is that it can be used to analyse data after the phenomenon at issue has occurred.

In this study the existing condition is online learning. Locus of control is the variable that might have an influence on the existing condition.

\section{Sample}

The study population consisted of 586 first-year learners enrolled for a compulsory Business Science course at a large South African university.

TABLE 1

COMPOSITION OF SAMPLE

\begin{tabular}{lccc}
\hline & LCI completed & LCI not completed & Total \\
\hline Online & 90 & 151 & 241 \\
Conventional & 95 & 228 & 323 \\
Total & 185 & 379 & 564 \\
\hline
\end{tabular}

The composition of the sample is presented in Table 1 . Of the total population of 564 learners, 241 (43\%) voluntarily made use of online support while $323(57 \%)$ did not use the online support that was offered. Only $90(37,3 \%)$ of the 241 learners who made use of online learning completed the LCI and only 95 $(29,4 \%)$ of the 323 learners who did not use online learning completed the LCI.

Most of the learners lived in residences on campus and had access to computers 24 hours a day.

\section{Measuring instruments}

To determine the locus of control (the primary variable) of each one of the respondents the Locus of Control Inventory (LCI) devised by Schepers (1994, revised in 1999) was used. The 1994 LCI consisted of 65 items; in 1995 it was extended to 80 items and in 1998 to 88 items (Schepers, 1995). After it was again revised in 1999 it was applied to 2091 first-year learners (Schepers, 1999). The reliability and validity of this instrument for assessing a person's locus of control have been confirmed. The LCI has 88 items and respondents use a 7-point Likert-type scale (from $1=$ not at all, to $7=$ to a great extent) to indicate the degree to which each statement describes their own feelings. 
Of the 88 items, 34 measure autonomy (scale 1), 26 external control (scale 2) and 28 internal control (scale 3). In a factor analysis of the LCI, Schepers (1999) identified three factors:

\section{Autonomy}

The individual functions autonomously and prefers working alone. This factor determines whether respondents are able to believe in their own abilities, can act independently with selfconfidence, can take decisions on their own and can take action steps that will lead to problem solving (Rothmann \& Agathagelou, 2000).

\section{Internal control}

The individual believes that outcomes are a consequence of his/her own behaviour. According to Rothmann and Agathagelou (2000) this factor determines whether respondents ascribe achievements to causes within their own control (abilities, behaviour and personal characteristics).

\section{External control}

The individual believes that outcomes are independent of his/her own behaviour and are determined by external factors. According to Rothmann and Agathagelou (2000) this factor determines the extent to which respondents ascribe achievement to causes outside their own control (fortune, fate, circumstances or influential people).

High internal consistency of the LCI, determined by means of Cronbach's alpha reliability coefficient, was reported by Schepers (1999) in respect of each of the three scales. (The Cronbach alpha reliability coefficient for autonomy (scale 1) is 0,884 , for external control (scale 2) 0,871 , and for internal control (scale 3) 0,822.)

The study by Rothmann and Agathagelou (2000) confirms the high internal consistency of the LCI, in respect of each of the three scales. (They found the Cronbach alpha reliability coefficient for autonomy (scale 1 ) to be 0,72 , for external control (scale 2) 0,81 , and for internal control (scale 3) 0,77 .) These alpha coefficients are all greater than the value of 0,7 , which is seen as acceptable by Nunnally (1978).

\section{Research procedure}

The LCI was distributed to the learners during their last lecture in the Business Science course at the Rand Afrikaans University (RAU) in order to collect data on the locus of control variable for each learner. They had to record their responses on a standardised answer sheet. Only 188 of the learners completed valid LCIs. They also completed a general biographical questionnaire.

\section{Statistical analysis of the data}

STATCON at RAU did the statistical analysis of the data.

An analysis of variance (ANOVA) was used to determine whether the respondents differed statistically significantly on the mean test scores for, first, the overall locus of control of the whole group and, second, the three different scales of locus of control.

The multiple analysis variance (MANOVA) and Hotelling's $\mathrm{T}^{2}$ test for independent samples were applied to determine whether the vectors of means of test scores of the two groups, namely those respondents who participated in online learning (group 1) and those who did not (group 2), differed statistically significantly in respect of locus of control.

\section{RESULTS}

The results of the study are reported first in terms of biographic and demographic characteristics and second in terms of the analysis of variance with respect to locus of control.
TABLE 2

Age Distribution

\begin{tabular}{lcccc}
\hline $\begin{array}{l}\text { Frequency } \\
\text { (Age) }\end{array}$ & Percent & Valid percent & Cumulative percent \\
\hline Younger than 18 & 45 & 23,9 & 27,4 & 27,4 \\
18 years & 105 & 55,9 & 64,0 & 91,5 \\
19 years & 10 & 5,3 & 6,1 & 97,6 \\
20 years & 3 & 1,6 & 1,8 & 99,4 \\
Older than 20 & 1 & 0,5 & 0,6 & 100,0 \\
Total & 164 & 87,2 & 100,0 & \\
\hline
\end{tabular}

Age distribution is presented in Table 2. The table shows that $27,4 \%$ of the respondents were younger than 18 years, $64 \%$ were 18 years old, $6,1 \%$ were 19 years old, $1,8 \%$ were 20 years old and $0,6 \%$ were older than 20 years.

TABLE 3

NUMBER OF MEN AND WOMEN WHO COMPLETED THE LCI

\begin{tabular}{lcccc}
\hline & Frequency & Percent & Valid percent & $\begin{array}{c}\text { Cumulative } \\
\text { percent }\end{array}$ \\
\hline Women & 106 & 56,4 & 59,6 & 59,6 \\
Men & 72 & 38,3 & 40,4 & 100,0 \\
Total & 178 & 94,7 & 100, & \\
\hline
\end{tabular}

Table 3 shows that 106 women $(59,6 \%)$ and 72 men $(40,4 \%)$ completed the LCI.

TABLE 4

Preferred language of Respondents

\begin{tabular}{lcccc}
\hline & Frequency & Percent & Valid percent & $\begin{array}{c}\text { Cumulative } \\
\text { percent }\end{array}$ \\
\hline Alternative & 3 & 1,6 & 1,7 & 1,7 \\
English & 175 & 93,1 & 98,3 & 100,0 \\
Total & 178 & 94,7 & 100,0 & \\
\hline
\end{tabular}

Table 4 presents the preferred language of the respondents. Altogether $175(98,3 \%)$ of them indicated that English was their preferred language, while $3(1,7 \%)$ indicated that they would prefer another language.

TABLE 5

Cross-Tabulation OF AGE AGAINST TYPE OF LEARNER (ONLINE VS CONVENTIONAL)

\begin{tabular}{lcccc}
\hline & \multicolumn{3}{c}{ Age group } & Total \\
\cline { 2 - 4 } & $\begin{array}{l}\text { Younger } \\
\text { than } \mathbf{1 8}\end{array}$ & $\begin{array}{c}\mathbf{1 8} \text { years } \\
\text { than } \mathbf{1 8}\end{array}$ & Older & \\
\hline Online & 20 & 52 & 7 & 79 \\
Conventional & 24 & 51 & 7 & 82 \\
Total & 44 & 103 & 14 & 161 \\
\hline
\end{tabular}

The cross-tabulation of age against type of learner (online versus conventional) in Table 5 indicates that the respondents consisted of 44 learners who were younger than 18 years, 103 who were 18 years old and 14 who were older than 18 years. 
Online learning was chosen by $20(45,5 \%)$ of the 44 learners who were younger than 18 years, $52(50,5 \%)$ of the 103 learners who were 18 years old, and $7(50 \%)$ of the 14 learners who were older than 18 years.

TABLE 6

ChI-SQUARE TEST: AGE AGAINST TYPE OF LEARNER (ONLINE VS CONVENTIONAL)

\begin{tabular}{lccc}
\hline & Value & df & Asymp. sig. (2-sided) \\
\hline Pearson chi-square & $0,318(\mathrm{a})$ & 2 & 0,853 \\
\hline
\end{tabular}

$(\mathrm{p} \leq 0,05)$

The chi-square of age against type of learner (online versus conventional) in Table 6 indicates that there was no statistically significant difference $(p \leq 0,05)$ the different age groups with regard to participation in online or conventional learning.

TABLE 7

Cross-TABUlation: GENDER AGAINST TYPE OF LEARNER (ONLINE VS CONVENTIONAL)

\begin{tabular}{lccc}
\hline & \multicolumn{2}{c}{ Gender } & Total \\
\cline { 2 - 3 } & F & M & \\
\hline Online & 48 & 38 & 86 \\
Conventional & 57 & 32 & 89 \\
Total & 105 & 70 & 175 \\
\hline
\end{tabular}

The cross-tabulation of gender against type of learner in Table 7 shows that $48(45,7 \%)$ women out of 105 chose to participate in online learning as opposed to $38(54,3 \%)$ men out of 70 . The chisquare test in Table 8 confirms that there was not a statistically significant difference $(p \leq 0,05)$ between the number of men and women who participated in online learning, suggesting that online learning was not dependent on age.

\section{TABLE 8}

CHI-SQUARE TEST: GENDER VS TYPE OF LEARNER (ONLINE VS CONVENTIONAL)

\begin{tabular}{|c|c|c|c|c|c|}
\hline & Value & df & $\begin{array}{l}\text { Asymp. sig. } \\
\text { (2-sided) }\end{array}$ & $\begin{array}{l}\text { Exact sig. } \\
\text { (2-sided) }\end{array}$ & $\begin{array}{l}\text { Exact sig } \\
\text { (1-sided }\end{array}$ \\
\hline Pearson chi-square & 1,235 (b) & 1 & 0,267 & & \\
\hline Fisher's Exact Test & & & & 0,284 & 0,169 \\
\hline $\mathrm{N}$ of valid cases & 175 & & & & \\
\hline
\end{tabular}

$(\mathrm{p} \leq 0,05)$

TTABLe 9

Cross TABUlation: GENDER VS COMPUTER LITERACY

\begin{tabular}{lccc}
\hline Computer literacy & \multicolumn{2}{c}{ Gender } & Total \\
\cline { 2 - 3 } & F & M & \\
\hline 1-3: Not at all & 37 & 12 & 49 \\
4 & 31 & 16 & 47 \\
5 & 26 & 20 & 46 \\
6-7: Very good & 12 & 24 & 36 \\
Total & 106 & 72 & 178 \\
\hline
\end{tabular}

The cross-tabulation of gender against computer literacy in Table 9 shows that more men than women described themselves as very computer literate. Of the 106 women, 12 $(11,3 \%)$ described themselves as very computer literate and of the 72 men, $24(33,33 \%)$ described themselves as very computer literate.

TABLE 10

ChI-SQUARE TEST: GENDER vS COMPUTER LITERACY

\begin{tabular}{lccc}
\hline & Value & df & $\begin{array}{c}\text { Asymp. sig. } \\
\text { (2-sided) }\end{array}$ \\
\hline Pearson chi-square & $16,430(a)$ & 3 & $0,001^{*}$ \\
N of valid cases & 178 & & \\
\hline
\end{tabular}

$*(\mathrm{p} \leq 0,05)$

The chi-square test in Table 10 confirms that there was a statistically significant difference $(p \leq 0,05)$ between the number of female respondents who described themselves as computer literate and the number of male respondents who described themselves as computer literate. It seems that the men in this population were more computer literate than the women.

TABLE 11

RELIABILITY ESTIMATES OF LCI SCALES

\begin{tabular}{lccc}
\hline Measures & $\mathbf{N}$ & Number of items & Alpha \\
\hline Autonomy & 188 & 32 & 0,8491 \\
External & 188 & 26 & 0,8691 \\
Internal & 188 & 28 & 0,8781 \\
\hline
\end{tabular}

The reliability estimates of the LCI scales presented in Table 11 give Cronbach's alpha reliability coefficient of the LCI. High internal consistency was obtained for this specific group in respect of each of the three scales. The Cronbach alpha reliability coefficient for autonomy (scale 1) was 0,8491 , for external control (scale 2) 0,8691, and for internal control (scale 3 ) 0,8781 . (Internal consistency reliabilities ranging from 0,80 to 0,90 are usually acceptable, but reliabilities in the 0,60 to 0,70 range may still be viewed as adequate for research purposes (Clark \& Watson, 1995). The high reliability coefficients of the LCI previously established by Schepers are confirmed by this (South African) study. The instrument was therefore judged to possess adequate psychometric properties for the purpose of this study.

TABLE 12

ONE-WAY ANALYSIS OS VARIANCE (ANOVA): COMPARISON OF THE MEANS OF THE TWO GROUPS IN RESPECT OF LOCUS OF CONTROL

\begin{tabular}{lccccc}
\hline $\begin{array}{l}\text { Dependent } \\
\text { variable }\end{array}$ & d.f. & $\begin{array}{c}\text { Sum of } \\
\text { squares }\end{array}$ & $\begin{array}{c}\text { Mean } \\
\text { square }\end{array}$ & F & p value \\
\hline Autonomy & 1 & 59,267 & 59,267 & 0,185 & 0,667 \\
External & 1 & 67,200 & 67,200 & 0,186 & 0,667 \\
Internal & 1 & 156,924 & 156,924 & 0,583 & 0,446 \\
\hline
\end{tabular}

$(\mathrm{p} \leq 0,05)$

From an inspection of the ANOVA, which presents a comparison of the means of the two groups in respect of locus of control in Table 12 , it is clear that the $p$ values are all greater than the significant level $(\mathrm{p} \leq 0,05)$. 
TABLE 13

MEANS AND STANDARD DEVIATIONS OF THE TWO GROUPS IN RESPECT OF LOCUS OF CONTROL

\begin{tabular}{lcccccc}
\hline & \multicolumn{3}{c}{ Online } & \multicolumn{3}{c}{ Conventional } \\
\hline $\begin{array}{l}\text { Locus of } \\
\text { control }\end{array}$ & Mean & $\begin{array}{c}\text { Std. } \\
\text { deviation }\end{array}$ & $\mathrm{N}$ & Mean & $\begin{array}{c}\text { Std. } \\
\text { deviation }\end{array}$ & $\mathrm{N}$ \\
\hline Autonomy & 159,7 & 18,595 & 90 & 158,56 & 17,182 & 90 \\
External & 90,130 & 19,553 & 90 & 91,336 & 18,522 & 95 \\
Internal & 158,340 & 18,700 & 90 & 160,180 & 13,886 & 95 \\
\hline
\end{tabular}

$[\mathrm{F}(6,240)=1,850 ; \mathrm{p}=0,085]$

From the means and standard deviations of the two groups in respect of locus of control presented in Table 13 it is apparent that there was no statistically significant difference between the vectors of means of the three scales of locus of control of the two groups. The $p$ value was also not significant $(p=0,085)$, because $\mathrm{p}>0,05$.

TABLE 14

MULTIVARIATE TESTS OF SIGNIFICANCE

\begin{tabular}{lccccc}
\hline & Value & $\mathrm{F}$ & $\begin{array}{c}\text { Hypothesis } \\
\text { Df }\end{array}$ & Error df & $\mathrm{P}$ \\
\hline Hotelling's Trace & 0,010 & 0,588 & 3,000 & 181 & 0,624 \\
\hline
\end{tabular}

[F $(3,181)=0,588 ; \mathrm{p}=0,624]$

According to Cooper and Schindler (2001) this test is analogous to a t-test or $\mathrm{F}$ test for multivariate data. Sum of squares and cross-products (SSCP) matrices were used. The multivariate tests of significance presented in Table 14 show the Hotelling $\mathrm{T}^{2}$ test $F(3,181)=0,588 ; p=0,624$. This test was compared to the $\mathrm{F}$ distribution for interpretation. Since the observed significance levels were greater than $\mathrm{p}=0,05(\mathrm{p}=$ 0,624 ) for the $T^{2}$ test, the null hypothesis was not rejected and the alternative hypothesis HA was therefore not supported. This means that the vectors of means of the two groups with respect to locus of control did not differ statistically significantly from one another.

\section{DISCUSSION}

The principal aim of this study was to determine whether there were significant differences between online university learners and conventional university learners with respect to locus of control.

In the light of the findings, the null hypothesis was not rejected and the alternative hypothesis HA was therefore not supported. This means that the vectors of means of the two groups with respect to locus of control did not differ statistically significantly from one another. This implies that the learners' locus of control was not a determining factor in online learning.

Moore and Kearsley (1996) reviewed distance education research over the previous 50 years. They compared test scores, grades, retention and job performance of distance learners with those of learners who learned face-to-face. According to the authors the reviewed research indicated that, regardless of the nature of the content, the educational level of the learners, or the media involved, there were no significant differences between learning in the two environments.

Schlosser and Anderson's (1997) review of distance education research indicates that learners learn equally well from courses presented through various media. In other words, there is no inherent significant difference in the educational effectiveness of media; learners learning at a distance (like online learners) have the potential to learn just as much and as well as learners taught in the conventional way.

The findings of this study support the large body of literature indicating that distance delivery, regardless of media or technology used, is not by itself a contributing variable in learner achievement (Moore \& Kearsley, 1996; Schlosser \& Anderson, 1997; Russell, 1998).

The results of this study underscore that the driving force behind the decision to get involved in online learning is not seated in the learner only. There are other factors that play a role, like motivation. If there is a reason for the learner to participate in online learning and if the learner is assessed on the activity in the online environment, the learner will become involved irrespective of locus of control.

The problem lies with the fact that only a few learners will participate in activities for which there is no recognition in the form of assessments. If they are just told that they can get involved in online learning, there might not be a strong call to action. In order to ensure that learning will take place in an online learning environment, it is necessary for the facilitator to drive the learning process. There rests a big responsibility on the facilitator of learning to create motivators for learning. Horton (2000) says that online learning is difficult for learners because it raises technical hurdles, the rules for social interaction are uncertain and the immediate camaraderie of face-to-face learning is missing. Successful online learning will only take place if the online course relies on the selfdiscipline and focus of motivated learners. Online learning demands high levels of motivation, and facilitators of learning cannot depend on the learners to bring all the required motivation with them - the online learning must motivate the learner (Horton, 2000).

Motivation will speak to the heart of the learner and open up the channel from the heart to the head. When this channel is open, the learner will start acting with a goal in mind in a way that will prove that he or she understands why it is necessary to get involved.

It is true that some time spent in the classroom simply conveying information could be better spent by learners gathering information through the use of an online learning environment. The online learning environment on its own will however not provide the optimum solution for the future.

According to Horton (2000) online learning does not change how humans learn, but it does change how they can be taught. It also does not change the fundamental responsibility of the facilitator of the learning. His/her responsibility remains to create an experience that causes someone else to learn. What online learning changes are the economics and capabilities of delivering learning opportunities. Online learning makes it easier and less expensive to produce certain kinds of learning experiences for people at a distance (Horton, 2000).

As part of a total integrated learning programme, the online learning environment offers a myriad of benefits. However, learners need interaction. Facilitators must give them feedback on the activities they performed in online learning. In a study by Gagne and Shepherd (2001) learners in online courses indicated that they were less satisfied than the conventional learners with the instructor's availability. The online learning environment has allowed the facilitator to become much more flexible, encompassing the multiple roles of mentor, coach and facilitator. There can be no question that facilitators have played and will always play a vital role in the learning process. 
The introduction of new learning methods in online learning environments should therefore complement facilitators and not eliminate them.

According to Moore and Kearsley (1996) distance learning (which includes online learning) is as effective in bringing about learning as face-to-face instruction, and the absence of face-toface contact is not in itself detrimental to the learning process. What makes any course good or poor is a consequence of how well it is designed, delivered and conducted, not whether the learners are face-to-face with or at a distance from the facilitator (Moore \& Kearsley, 1996). Facilitators should therefore pay great attention to the design and conduction of online courses just as they have always done with face-to-face courses, in order to ensure the effectiveness of the learning experience.

Undoubtedly self-selection means that learners with greater computer skills and/or greater maturity are more likely to opt for online courses (Dutton, Dutton \& Perry, 1999). Other limitations are imposed on the study as a result of the choice of an ex post facto research design. Such a design does not allow for controls because it is after the fact and limits interpretations, and one cannot determine ahead of time what is being looked at.

This is an exploratory-descriptive study based on a sample from a specific population. The results should therefore be used with extreme caution. More studies are necessary to determine whether or not the present findings can be generalised to other populations.

A further opportunity for research lies in the identification of predictor variables with regard to a learner's decision to participate in online learning. This research could be valuable to designers of online learning material and facilitators because it could assist them to find effective ways to enhance online learning. Furthermore, it will be very valuable to perform a qualitative study to determine the reasons why learners choose not to become involved in online learning.

\section{REFERENCES}

Berry, J. (2000). Traditional training fades in favor of e-learning. Internetweek, 33-35.

Biggs, J.B. (1985). The roles of metalearning in study processes. British Journal of Educational Psychology, 55, 185-212.

Bothma, A.C. \& Schepers, J.M. (1997). The role of locus of control and achievement motivation in the work performance of black managers. Journal of Industrial Psychology, 23 (3), 44-52.

Brown, K.G. (2001). Using computers to deliver training: Which employees learn and why? Personnel Psychology, 54 (2), 271.

Burger, J.M. (1992). Desire for control. Personality, social, and clinical perspectives. New York: Plenum Press.

Burrows, T. (2002). Is e-learning worth the e-effort? IT Web Brainstorm, 6 (6), 54-58.

Causal-comparative (ex post facto) research. Available from www.cedu.niu.edu/ smith//PP_presentation/15_causalcomp. ppt. (Accessed on 19 November 2002.)

Charp, S. (1999). Internet impact. T H E Journal, 27 (4), 8-10

Clark, L.A. \& Watson, D. (1995). Constructing validity: Basic issues in objective scale development. Psychological Assessment, 7 (3), 309-319.

Clemans, W.V. (1956). An analytical and empirical examination of some properties of ipsative measures. Psychometric Monograph Number 14.

Cooper, D.R. \& Schindler, P.S. (2001). Business research methods (7th ed). New York: Irwin/McGraw-Hill.

Davies, D. (1998). The virtual university: A learning university. The Journal of Workplace Learning, 10 (4), 175-213.

Davis, R.D. \& Davis, A.B. (2000). Managing your own learning. San Francisco: Berrett-Koehler Publishers, Inc.
De Charms, R. (1968). Personal causation. New York: Academic Press.

De Kock, F.G. \& Roodt, G. (1995). Die effek van intelligensie op die verhouding tussen lokus van kontrole en taakkompleksiteit. Tydskrif vir Bedryfsielkunde, 21 (3), 12-17.

Dille, B. \& Mezack, M. (1991a). Identifying predictors of high risk among community college telecourse students. The American Journal of Distance Education, 2, 25-27.

Dille, B. \& Mezack, M. (1991b). Identifying predictors of high risk among community college telecourse students. The American Journal of Distance Education, 5 (1), 24-35.

Dollinger, S.J. (2000). Locus of control and incidental learning: An application to college student success. College Student Journal, 34 (4), 537. (Accessed on Infotrac on 18 October 2001.)

Driscoll, M. (1998). Web-based training. San Francisco: JosseyBass/Pfeiffer.

Dutton, J., Dutton, M. \& Perry, J. (1999). Do online students perform as well as traditional students? Submitted for publication, North Carolina State University. Available from http://www.teleeducation.nb.ca/nosignificantdifference/ind ex.cfm. (Accessed on 19 November 2002.)

Erwee, R. (1986). Achievement motivation and locus of control of black university students. Journal of Industrial Psychology, 12 (2), 1-9, Rand Afrikaans University.

Follows, S.B. (1999). Virtual learning environments. $T H E$ Journal, 27 (4), 100.

Gagne, M. \& Shepherd, M. (2001). Distance learning in Accounting. A comparison between a distance and traditional graduate accounting class. TH E Journal, 28 (9), 58-65.

Galagan, P.A. (2000). Getting started with e-learning. Training \& Development, 54 (5), 62.

Garten, E.D. (2000). Providing intellectual resources through technology to transnational virtual universities: Good practice and lessons learned from world-class examples. Higher Education in Europe, 25 (3).

Goldschmidt, M. (2001). E-learning essential for SA economy. Available from http://www.itweb.co.za/sections/techforum/ 2001/0104190831.asp?A=EBU\&O=H. (Accessed on 8 February 2002.)

Goldsmith, D.J. (2001). Communication, humor, and personality: Student's attitudes to learning online. Academic Exchange Quarterly, 5 (2), 108.

Hall, B. (1997). Web-based training cookbook. New York: Wiley.

Hengstler, J.E.W. (2001). Key factors in adolescent distributed learning. Academic Exchange Quarterly, 5 (2), 43.

Higher education's role in the digital age. (1999). Newsline, 8 (1), January, 4-8. History \& Archives. Available from http://www.chautauqua-inst.org/homebase.html. (Accessed on 12 November 2002.)

Horton, W. (2000). Designing web-based training. New York: John Wiley \& Sons, Inc.

Ishiyama, J.T.; McClure, M.; Hart, H. \& Amico, J. (1999). Critical thinking disposition and locus of control as predictors of evaluation of teaching strategies. College Student Journal, 33 (2), 269

Knasel, E., Meed, J. \& Rossetti, A. (2000). Learn for your life. A blueprint for continuous learning. London: Pearson Education.

Kruse, K. \& Keil, J. (2000). Technology-based training. JosseyBass/Pfeiffer.

Lau, V.P. \& Shaffer, M.A. (1999). Career success: The effects of personality. Career Development International, 4 (4), 225-231.

Lee, W.W. \& Owens, D.L. (2000). Multimedia-based instructional design. San Francisco: Jossey-Bass/Pfeiffer.

Lefcourt, H.M. (1976). Locus of control: Current trends in theory and research. New Jersey: Lawrence Erlbaum Associates Publishers.

Leone, C. \& Burns, J. (2000). The measurement of locus of control: Assessing more than meets the eye? Journal of Psychology, 134 (1), 63.

Le Roux, C.A., Schmidt, C. \& Schepers, J.M. (1997). Achievement motivation, locus of control and individuality as predictors of participative management in the South African educational environment. Journal of Industrial Psychology, 23 (3), 1-8. 
Littlejohn, A. \& Sclater, N. (1999). The virtual university as a conceptual model for faculty change and innovation. Interactive Learning Environments, 7 (2-3), 209-225.

Live e-learning. Available from http://www.campuswise.co.za/ campuswise/index3.htm. (Accessed on 11 May 2001.)

McFadzean, E. (2001a). Supporting virtual learning groups. Part 1: A pedagogical perspective. Team Performance Management, $7(3,4), 53-62$.

McFadzean, E. (2001b). Supporting virtual learning groups. Part 2: An integrated approach. Team Performance Management, 7 $(4,5), 77-93$

Moore, M. \& Kearsley, G. (1996). Distance education: A systems view. Belmont, CA: Wadsworth.

Morgan, A.R. (1996). Improving student learning in distance education: Theory, research, and practice. European Journal of Psychology of Education, 10 (2), 121-130.

Mouton, J. \& Marais, H.C. (1991). Basiese begrippe: Metodologie van die geesteswetenskappe. Pretoria: Gutenberg Boekdrukkers.

Nunnally, J. (1978). Psychometric theory (2nd ed). New York: Wiley.

O'Brien, G.E. (1986). Psychology of work and unemployment. New York: Wiley.

Piskurich, G.M. (1993). Self-directed learning. San Francisco: Jossey-Bass Publishers.

Rieger, H.S. \& Blignaut, C.J.H. (1996). Individualiteit, kollektiwiteit en lokus van beheer as mikroveranderlikes van diversiteit. Journal of Industrial Psychology, 23 (3), 35.

Rose, R.J., Hall, C.W., Bolen, L.M. \& Webster, R.E. (1996). Locus of control and college students' approaches to learning. Psychological Reports, 79, 163-171.

Rothmann, S. \& Agathagelou, A.M. (2000). Die verband tussen lokus van beheer en werkstevredenheid by senior polisiepersoneel. Journal of Industrial Psychology, 26 (2), 20-26.

Rotter, J.B. (1966). Generalized expectancies for internal versus external control of reinforcement. Psychological Monographs: General and applied. 80 (1), 1-27

Russell, T. (1998). The no significant difference phenomenon. Available from http://teleeducation.nb.ca/phenom/. (Accessed on 8 November 2002.)

Russell, T. (2002). The no significant difference phenomenon. Available from http://teleeducation.nb.ca/phenom/ (Accessed on 12 November 2002).

Santo, S.A. (1999). Virtual learning and personality. http://www.aln.org/alnconf.99/presentations/convertedfiles/ 3/sld003.htm. (Accessed on 26 October 2001.)
Schepers, J.M. (1994). Die Lokus van Beheer-vraelys: Konstruksie en evaluering van 'n nuwe meetinstrument. Unpublished report. Rand Afrikaans University, Johannesburg.

Schepers, J.M. (1995). Die Lokus van Beheer-vraelys: Konstruksie en evaluering van 'n nuwe meetinstrument. Unpublished report. Rand Afrikaans University, Johannesburg.

Schepers, J.M. (1999). Scoring key of locus of control inventory. Unpublished report. Rand Afrikaans University, Johannesburg.

Schlosser, C.A. \& Anderson, M.L. (1994). Distance education: Review of the literature. Monograph prepared for the Iowa Distance Education Alliance. Washington, DC: AECT Publications.

Schlosser, C.A. \& Anderson, M.L. (1997). Distance education: Review of the literature. Monograph prepared for the Iowa Distance Education Alliance. Washington, DC: AECT Publications.

Smith, G.G., Ferguson, D. \& Caris, M. (2001). Online vs. face-toface. $T$ H E Journal (Technological Horizons in Education), 28 (9), 18.

Steinberg, E.R. (1989). Cognition and learner control: A literature review, 1977-1988. Journal of Computer-Based Instruction, 16, 117-121.

Stone, G. \& Jackson, T. (1975). Internal-external control as a determinant of effectiveness of modelling and instructions. Journal of Counseling Psychology, 22, 294-298.

Tennyson, R.D. (1980). Instructional control strategies and content structure as designed variables in concept acquisition using computer-based instruction. Journal of Educational Psychology, $72,525-532$

Types of Research Ends Sought of Research. Available from http://www.ais.msstate.edu/AEE/8803/class4/ts1001.htm. (Accessed on 19 November 2002.)

Van Staden, J.F., Schepers, J.M. \& Rieger, H.S. (2000). Lokus van beheer en transformasionele leierskap. Journal of Industrial Psychology, 26 (3), 8-14.

Van Tonder, M. (2001). E-learning takes off. Available from http://www.itweb.co.za/sections/techforum/2001/01022608

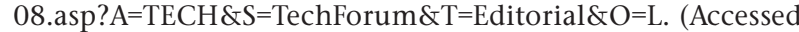
on 12 May 2001.)

Wang, A.Y. \& Newlin, M.H. (2000). Characteristics of students who enroll and succeed in Psychology web-based classes. Journal of Educational Psychology, 92 (1),137-143.

Williams, T.C. \& Zahed, H. (1996). Computer-based training versus traditional lecture: Effect on learning and retention. Journal of Business and Psychology, 11, 297-310.

Worthington Smith, R., Rockey, N., Siebert, G. \& Hartley, P. (2001). The e-Business Handbook ( $2^{\text {nd }}$ ed). Cape Town: Trident Press. 